\title{
Women Empowerment: A Study of Media and its Role in Empowerment of Afghan's Women
}

\author{
Mostafa Hassanzadeh* \\ Osmania University, Amberpet, Hyderabad - 500007, Telangana, India; \\ iaum2013@gmail.com
}

\begin{abstract}
During the last fourteen years, Afghan media has played a significant role in empowering women and they still do. Media has a crucial responsibility in promoting women's participation in society. It has the power to spread messages and raise awareness for the challenges women face. Most importantly, media has given women a voice which has allowed them to actively engage with the Afghan government, interest groups and society at large. This paper is about Afghan women print media, focusing on media representation of Afghan women in the Afghan women's print media in post-Taliban Afghanistan. The Afghan women's media has been studied to find out how Afghan women are represented and how it impacts women's social condition in Afghanistan. A textual analysis of Afghan women's magazines provided the research material for this study. Feminist theory is used to determine the effect of Afghan women media representation in the post-Taliban period on the perception of women in the Afghan society.
\end{abstract}

Keywords: Afghan Women's Media, Afghan Women's Rights, Empowering Women, Women Representation

\section{Introduction}

Empowerment is an active and multidimensional process which enables women to realize their full identity and powers in all spheres of life (Pillai, 1995).Empowerment refers to increasing the spiritual, political, social or economic strength of individuals and communities. It often involves the empowered developing confidence in their capacities. Women's empowerment has five components: women's sense of self-worth; their right to have and to determine choices; their right to have access to opportunities and resources; their right to have the power to control their own lives, both within and outside the home; and their ability to influence the direction of social change to create a more just social and economic order, nationally and internationally ${ }^{1}$.

Afghan women experienced traumatized social life during the Taliban regime. During that time "Afghan women, who were traditionally forced to live under male domination, now were confronted with a religious extremism that sought to maintain them in submission and the treatment was cruel to an extent that is hard to describe" 2 . The five years of the Taliban regime caused Afghan women to suffer more than at any other time. Afghan women under the Taliban regime were imprisoned in their homes, denied access to education, health care, and work. A restrictive dress code was enforced and women had to have a husband, brother or father accom-

${ }^{*}$ Author for correspondence 
pany them outside of their home. "Afghan women living under the Taliban virtually had the world of work closed to them" doctors, nurses, and clerical workers, and forget about their existence as free human beings.

After the fall of the Taliban regime, international news channels covered the domestic and political violence against women in Afghanistan. People around the world knew Afghan women through international news, which created an image of Afghan women as the most oppressed and vulnerable group in Afghanistan and that is basically accurate. After the fall of Taliban and establishment of new government, the political and cultural position of Afghan women has improved substantially. As Flanders stated in her report on Afghan women entitled Speak Behind the Media Veil (2001) "we have begun to see a lot in the media lately about the oppression of women under the Taliban. We have begun, finally, to hear about the women whom the Taliban ban from working, keep out of school, flog because of wearing makeup, even execute" (Flanders, 2001, p.2). Such reports have observed a change after the fall of the Taliban in regard to women activities in Afghanistan, indicating that the social space for women has expanded and now in most areas i.e. big cities women go to school, work outside their homes and participate in social affairs.

\section{Growth of Media and Challenges}

The vast growth of free media in Afghanistan over the past decade has provided employment opportunities for a large number of journalists and other media workers in the country. However, this growth has also come with difficulties, among which is the challenging work environment female journalists face. In order to better understand the condition of Afghan female journalists, it is necessary to consider two aspects: first, the overall environment of Afghanistan and the position of women within it, and second, the general condition of journalists in the country. Gender discrimination and sexual harassment are two of the many social ills that Afghanistan has inherited in part as a result of decades of war. These problems also come as the direct products of the traditions and customs prevailing in Afghan society. In the traditional and patriarchal society of Afghanistan, being born a woman can mean a lack of access to many social opportunities and many barriers to success throughout life. Women in Afghanistan enjoy fewer privileges and less security than men. Traditionally male-dominated, public environments outside the home are often not safe for women, and studies have shown that the vast majority of Afghan women experience sexual harassment outside their homes. According to research by Thomson Reuters Foundation, Afghanistan is the most dangerous country for women in the world. In addition to being a difficult country in which to be born a woman, Afghanistan is among the most dangerous countries in the world for journalists and the free media. Since it began recording incidents in 2009, AJSC has recorded dozens of incidents of violence against journalists annually. These incidents speak to the unfavorable conditions the free media faces in Afghanistan. Given this backdrop of gender discrimination and hostility towards the free media, female media workers face intense challenges within the Afghan context. Female journalists in Afghanistan fight for their rights and livelihoods on two fronts. The first involves persuading their immediate family, close relatives and, in some instances, tribes, to grant them permission to work outside the house. Many families are opposed to their daughters and wives working outside the house and woman's decision to work in media usually isn't solely her own choice: relatives and acquaintances tend to get involved. In the cases women are able to obtain permission to work outside of their homes-usually following a lengthy struggle with family-and overcome the challenge of finding a job in the media, they then walk into a new realm of hostilities, stemming from individuals and groups who oppose free reporting and freedom of speech. 


\section{Women Improvement after Taliban}

After the fall of the Taliban, Afghan women gradually started to take part in the social affairs. Women were allowed to work and study and take part in elections. As a result, social space became open to Afghan women. Afghan women activists started advocating for pro-women changes in the country. Currently, there are many women's organizations working for women in Afghanistan along with the Ministry of women ${ }^{1}$ affairs. In addition to their general activities for women's empowerment, these groups use media to change the social position of Afghan women in Afghanistan. Right now in Afghanistan, we have women's magazines, filmmaking companies, and radio stations that are working closely with women rights organizations to address women's problems through their writings, plays, and talk shows. Their efforts are addressed to the Afghan government and to Afghan society in general. The representation of Afghan women through women's media is a mechanism to assist the process of change for Afghan women after the Taliban regime. With the presence of the Afghan women's media, it is anticipated that Afghan women working in the media will represent women through the eyes of Afghan women themselves. This paper represents how the Afghan women's print media presents Afghan women after the fall of the Taliban.

\section{Afghan Women's Print Media and it Affects the Perception of Women in Society}

It has been argued that the media representation of women has a huge impact on the development of positive or negative perceptions of women's images in any society. The dominant image of Afghan women wearing the Burqa in the media during the Taliban regime was subordinate, weak, oppressed, and vulnerable. Again it has been argued, that the negative representation of women in the media has negative impacts on the self-esteem and confidence of women as well as a negative impact on the perception of women in a society. The positive representation of women is argued to change the power relationship and create respect for women (Joshi, Pahad, and Maniar, 2006, p. 39). In the light of such arguments, this paper aims at studying the representation of Afghan women in the Afghan women print media between the periods from 2007 to 2015. The study focuses on analyzing the editorials of three Afghan women's magazines. The reason behind selecting the print media is that it is easier to track and identify the patterns of development of women issues discussed in the selected print media. Selecting the women media is justified by the fact that these are the places where women are expressing their views and thoughts and taking part in deliberations and discussions around women issues. Three magazines were selected among Afghan women's print media which have been active in Afghanistan for a comparatively longer period of time than other women's publications.

\section{Media and Women}

Directed by the media affect theories, numerous studies have been done on the media representation of women around the world. The objectives of such studies have been to figure out how media present women, and how does media representation of women affect their role and perception in a society. From the feminist media theory perspective, women representation in the women prints media has significant to make, points that can be translated and applied to the current paper. Women's media has always been successful in using themes and women empowerment agenda and placed them within certain contexts, meaning that convey the messages directly to the target audiences. As, DEBRA MERSKIN said in her article that women images "(re)presented, re(enforced), and repeated in the content of mass media and popular culture, had embedded the racist and sexist stereotypes in brands, labels, landforms, which is an exercise in power"4 Media representation Afghan women image through print media is an exercise of power to build a powerful 
image of new Afghan women in the post-Taliban regime. This is the exact context which I am looking for Afghan women print media representation of Afghan women, the common language, image, forms of words and meaning behind the context. The facts that how women are presented in their writing affect the image building of other Afghan women. The Feminine Mystique' Frieden raises the issue of magazines and how they endorse myths of fulfillment through domesticity in a chapter called 'The Happy Housewife Heroine' where she states that 'the image of... the suburban housewife with an up and coming husband and a station wagon full of children... this image- created by women's magazines, by advertisements, television, movies...shapes women's lives today and mirrors their dreams' (1963: p30). If Afghan women print media represent women as a doctor, teacher, politicians, member of parliament, engineers, independent this changes the socially constructed image of Afghan women in the media.

\section{The Role of Women's Media}

Media has an important and vital role in social change, by encouraging equality and social inclusion. Therefore, the emerging media in Afghanistan must make an effort to incorporate the rural perspectives of women into the regular media content and to challenge the pervasiveness of domestic violence, gender disparities in health and education, and gender discrimination. The emerging media can accomplish these aims through several means. First, the media can feature male change agents who have had a positive impact on the lives of women and girls. Second, the media can condemn both obvious and hidden forms of gender discrimination. Third, the media can introduce to the public positive images of women as experts, authorities, and skilled resources on various issues such as health, education, security, politics, and governance. Fourth, the emerging media can take steps to strengthen its investigative research capacity and employ it to examine and bring to light the effects of domestic violence on women's and children's health, and the need to further the education and political participation of women and girls. Besides this, women's media can play a role in breaking the taboos surrounding women's experiences since the media are a chronicler of events, an informer, an educator, a transformative space and a tool to change society. Afghan women's media can help this process of change for Afghan women because they have the knowledge of women's history, Afghan culture, and current challenges. Also, Afghan women's media is a mechanism through which Afghan women represent, educate and develop socially accepted discourse with other Afghan women and Afghan society as a whole.

\section{The Media and Rural Afghanistan: Neglected Terrain}

Educating and creating jobs for women and girls in rural Afghanistan is a major challenge for the current central government and its international allies. Afghanistan's emerging media can, and must, play a significant role in meeting this challenge. According to the 2004 Human Development Report, a rural woman knows four times less than a rural man about the constitutional process or the constitutional rights of Afghan citizens. This fact illustrates the ill effects of rural Afghan women's and girl's extremely limited access to information. The low social status of rural women and girls confines them to the immediate surroundings of her household. Yet, it is important to mention that among the rural Afghanistan, few men have access to modern forms of media, especially radio, and rarely to television due to geographic constraints and sparse socioeconomic opportunities. Meanwhile, illiteracy in the countryside defeats the possibility that communities can be reached through print media, magazines, or newspapers.

Unfortunately, the emerging Afghan media continues to neglect rural communities. The "typical" Afghan woman is still depicted as educated, modern, and a 
member of the working class, while the majority of the country's women are rural, uneducated, and have a very complicated lifestyle, which is different from those portrayed in national and private television channels. It is important to recognize the backlash and resistance in rural communities that such depictions can generate. As Homa Ghosh claims, rural Afghanistan is home to "the roots of tribal powers that have frequently doomed the Kabul-based modernization effort." Today's media, too, has overlooked the predominant role of the Afghan woman as a rural housewife or rural daughter - one who does not attend school and does not work outside the home. Rural women and girls are not able to relate their lives to the content of current media programs. This creates a backlash whereby there is growing resistance to the idea of educating and empowering women and the stigmatizing of women who are educated or who do work outside the home as dishonorable.

\section{Challenges and Obstacles for Afghan Journalist in Media}

According to some surveys especially AJSC Report, it is clear that female media workers face substantial obstacles in their work, both gender-related and universal to all journalists in the Afghan context. Social and cultural restrictions limit female mobility and increase women's vulnerability in the workplace. Women must strive to overcome extensive barriers to pursuing media work, including the family opposition, social pressures and strong stigmas and taboos. Despite a shortage of female workers, women often face difficulties securing a job in media. Upon entering the workforce, women continue to face substantial problems, including pay discrimination, harassment, violence, threats and psychological effects of their work.

Apart from sexual harassment, women also suffer from other forms of gender discrimination at the workplace. Common beliefs and cultural restrictions in the society have led to a lower public perception in the capability and potential of women to perform their work as well as their male counterparts. The patriarchal culture prevailing in the Afghan society has created barriers to women's success. As reported by participants in this research, women tend to receive lower pay, benefits and job security than their male counterparts in the workplace. In addition to the risks that all media workers face in the unpredictable, conflict environment of Afghanistan, female journalists are often intimidated and threatened because of their profession and gender. Relatives, acquaintances, and extremist religious groups that are opposed to women working outside the house are the most commonly responsible parties for these threats and intimidation. Female journalists are furthermore subjected to moral accusations that often negatively affect their personal lives, such as the opportunity to get married. Against these overwhelming odds, hundreds of female journalists continue their work in Afghanistan, with hundreds more studying journalism in various universities across the country, training to become the future of journalism in Afghanistan. To that end, it is not out of place to call female journalists heroes of Afghanistan; heroes fighting for freedom of expression, speech, livelihood and the future of female media workers in the country.

\section{Discussion and Conclusion}

The representation of women in media and its effect on women's behaviour and role in society has been an issue of interest to the media and social science researchers. Plenty of studies has been done on the topic. The study concluded that the "roles, which news media has represented to the public had their effect on public perception about a woman in that society because media decides about which information public should receive, see, listen, and read" study is that media representation of women can shape the perceptions and attitudes as well as the role of women in a society. The positive representation of women as strong, independent, educated and working in high-level 
positions would help other women to increase their confidence as well as shape a perception of women in a society which is respectful and trusting. Negative representation of women as marginal, passive, uneducated and dependent will have a negative impact on the self-esteem of women as well as shape a perception in a society which looks down at women. In Afghanistan, the representation of Afghan women as 'weak' and 'dependent' in the local culture has contributed into empowering masculine values and marginalizing the role of women in the society. Violence against women can only be understood from this perspective. The superiority of masculine values in a patriarchal culture justifies marginalization of women and use of violence against them. In Afghanistan, rightly put by Rooz editorial, "...due to inequality in the local culture, women are not able to practice their basic rights" (Rooz, 2009 No. 81). Women's ownership of the media can help them control the representation of women in media and create an independent voice for them. In terms of Pahad and Maniar's theory, the ideological control on women's self-perception is more likely when women own the media. In the context of the Afghan women's media, it is expected that the Afghan women's media will have the opportunity to challenge the existing women perception of them as weak and subordinate in the local culture. In the review of the editorials from the selected women's print media from a period between 2007-2015, it appears that Afghan women have got their independent voice, and are able to raise their concerns and take a position on the issues discussed in the Afghan society. This is a significant development if compared with a decade ago when international organizations spoke on behalf of Afghan women and demanded their rights. The behaviour of the Afghan women's media in terms of attempts to deconstruct the image of women through utilizing the religious texts and verses imply that a struggle has been in a place over ideological control over the issues of women. This is a challenge to the authority of the traditional religious institutions that have had a full control over women's issues for centuries in Afghanistan. From a power relation perspective, the struggle for the ideological control over the women's issues can have important implications for Afghan society. These implications include the perception of women as capable of communicating their role and identity and reflect on the society around. Theoretically, this might help produce a positive perception of women in Afghanistan.

The Afghan women's representation in the Afghan women's media provides a fruitful insight about how Afghan women are perceived in Afghanistan by women themselves, and how they are trying to address women's issues from an inner perspective. Afghan women's media also give a picture of "oppressed women". However, the Afghan women's media use the image of oppressed women as assign of protest rather than acceptance of their condition. Further, the discussion of women issues by the Afghan women's media shows that they are able to analyze the conditions that led to the oppression and violence against women. This is an important aspect of the Afghan women's media with women issues in Afghanistan which addresses the ideological control over women issues in Afghan society. In the process of ideological control over the perception and representation of women in Afghanistan, the Afghan women's media deal with two different images of women in Afghanistan in terms of inserting ideological control over their perception in the Afghan society. One is the new image of Afghan women who are free, independent, equal to men, and the other is traditional Afghan women, who did not have equal rights with Afghan men throughout the country's history. The emergence of Afghan women's media can help Afghan women 'reallocate their statuses in the Afghan society. Women's media can give a hand to Afghan women to affect cultural sensitivity toward a new image of Afghan women as well as pave the way for the public to accept these changes in Afghan society. This process needs local knowledge of Afghan society, courage and personal understanding of the Afghan women's position to represent modern Afghan women in an acceptable manner 
to a traditional society like Afghanistan. The analysis of the Afghan women's media presents a powerful case for Afghan women media's participation in changing the situation of the women in Afghanistan. During the Taliban, the dominant image of the Afghan women in the international media showed them as "weak, oppressed, and in need of liberation, they are seen as the victims of their own male-dominated culture" ${ }^{\prime}$. But now Afghan women's media are trying to represent them in a different way showing them struggling for equality and struggling to deconstruct the perception of the women in traditional Afghan society. This process of communication is likely to change the perception of women in Afghan society, giving women self-confidence and transforming the gender communication in Afghan society.

\section{References}

1. Behal A. Education, women empowerment and related issues. International Educational E-Journal. 2011 Oct-Dec; I(I).

2. Rahim T. An identity of strength: Personal thoughts on women in Afghanistan. International Rice Research Institute. 2002; 84(847):12-21. Crossref.

3. Rostami EP. Afghan Women: Identity and Invasion. Zed Books; 2007. p.159.

4. Merskin D. The S-word: Discourse, stereotypes, and the American Indian woman. The Howard Journal of Communications, School of Journalism and Communication, University of Oregon, Eugene, Oregon, USA; 2010.

5. Media Watch. Global media monitoring project: Women's participation in the news. Ontario: National Watch on Image of women/ Media Watch; 1995.

6. Havedal A. Afghan women and the western Left. Democratiya. 2007; 11:51-60.

7. Rostami EP. Women in Afghanistan: Passive victims of the burqa or active social participants?' Development in Practice. 2005; 13(2-3):266-77. Crossref.

8. Josh U, Pahad A, Maniar A. Images of Women in print media: A research inquiry. Indian Media Studies Journal. University of Baroda, Vadodara. 2006; 11(1):39-51.
9. Sahay S. Women and empowerment, Approaches and Strategies. New Delhi; 1998.

10. Bahma Z. Beyond the Burqa, New Internationalist Magazine. 2008 Nov 20; 417:3.

11. Sethnaa C. Animal sex: Purity Education and the Naturalization of the Abstinence; 2010.

12. Agenda, Institute of Women's Studies and Faculty of Health Sciences, University of Ottawa, Ottawa, Ontario, Canada

13. Fahmy S. Picturing Afghan women: A content analysis of AP wire photographs during the Taliban regime and after the fall of the Taliban regime. International Communication Gazette. 2004; 66(2):91-112. Crossref.

14. Gerson M. An Afghan feminism. The Washington post [Internet]. 2009 Jul 10. Available from: http://www.washingtonpost.com.

15. Gamson WA, Modigliani A. Media discourse and public opinion on nuclear power: A constructionist approach. American Journal of Sociology. 1989; 95(1):1-37. Crossref.

16. Hall S. Representation: Cultural representations and signifying practices. Newbury Park, CA: Saga Books; 1997. p. 386

17. Henderson-King D, Henderson-King EI, Hoffmann LL. Media images and women's self-evaluations: Social context and the importance of attractiveness as moderators. Personality and Social Psychology Bulletin. 2001; 27:140716. Crossref.

18. Katz E, Blumler JG, Gurevitch M. Uses and gratifications research. Public Opinion Quarterly. 1973; 37:509-23. Crossref.

19. Lazarsfeld PF, Berelson B, Gaudet H. The people's choice: How the voter makes up his mind in a presidential campaign. New York: Columbia University Press; 1948. PMid:18857808

20. Linda S. Creating unforgettable characters. Holt Rinehart and Winston; 1990. p. 256.

21. Vetten L. Reporting in rape in South Africa. Women's media watch newsletter; 1998. p. 3,5,8.

22. McCombs ME, Shaw DL. The agenda-setting function of mass media. Public Opinion Quarterly. 1972; 36:176-87. Crossref

23. Rahbani LN. Women in Arab media: Present but not heard, paper Presented at the Stanford University- California for a media conference,2010 Feb 16; 2010. p.1-28.

24. Rahimi WM. Status of women in Afghanistan, United Nations Educational, Scientific, and Cultural Organization (U N E S C O) Principal Regional Office for Asia and the 
Pacific, URUSHSAP Series on Monographs and Occasional; 1991. p. 31.

25. Rakow LF. Women making meanings: New feminism direction in communication. New York: Routledge; 1992. p. 302.

26. Lombard M, Snyder-Duch J, Bracken CC. Content analysis in mass communication: Assessment and reporting of intercoder reliability, human communication research. International Communication Association. 2002 Oct; 28(4):587-604. Crossref.
27. Hsieh H-F, Shannon SE. Three approaches to qualitative content analysis, qualitative health research. Sage Publications. 2005 Nov; 15(9):1277-88. Crossref. PMid:16204405

28. Elo S, Kynga“s H. The qualitative content analysis process. JAN Research Methodology, Blackwell Publishing Ltd; 2007.

29. The Reporting Heroes. A study on the condition of Afghan female journalists [Internet]. 2016. Available from: www. ajsc.af. 